\title{
sciendo
}

\section{The Impact of Supply Chain Dynamic Capabilities on Operational Performance}

\author{
Mohanad Ali KAREEM ${ }^{1}$, Harsha Vardhan Reddy KUMMITHA ${ }^{2}$ \\ ${ }^{1}$ Szent István University, Faculty of Economic Science, Kaposvár, Hungary, mohannadali25@gmail.com (Corre- \\ sponding author) \\ ${ }^{2}$ Budapest Business School, Department of Hospitality and Tourism Budapest, Hungary, \\ harshavardhankummitha@gmail.com
}

\begin{abstract}
Background and purpose: Literature is lacking on how supply chain dynamic capabilities influence operational performance. This study aims to empirically investigate the impact of supply chain dynamic capabilities on operational performance in Hungarian manufacturing companies.

Design/Methodology/Approach: The study used an online survey for data collection. The model is tested with data from 208 supply chain management professionals from Hungarian manufacturing industry. Structural equation modelling (SEM) was used to test the proposed hypotheses.

Results: The empirical results indicate that supply chain dynamic capabilities namely; collaboration capability, agility capability, and responsiveness capability are significantly and positively associated with operational performance. However, the results show that integration capability has no significant impact on operational performance Conclusion: The study concludes that in a dynamic environment, developing supply chain dynamic capabilities can help manufacturing company managers to build effective supply chains and achieve superior performance. Further, managers need to recognize that supply chain dynamic capabilities are multidimensional and each dimension has different effects on operational performance. Also, the study provides theoretical and managerial implications that are further idiscussed in detail.
\end{abstract}

Keywords: Dynamic capabilities, Supply chain, Operational performance

\section{Introduction}

The supply chain has become an increasingly significant area in business and academia. Due to the rapid economic growth, trends in globalization, and continuous changes in business environments. These challenges prevent firms from maintaining their competitive advantages through diagnosing the shifts in the business environment and sensing the opportunities and risks at the right time. Therefore, the key to survival in such situations requires the firms to develop capabilities that enable them to distinguish their processes over competitors. Thus, the sustainable competitive advantages and superior operational performance of a firm rely on its dynamic supply chain capability (Ju et al., 2016). In a rapidly changing environ- ment where uncertainty is high, ordinary efficiency-oriented supply chains are not appropriate enough to cope with the shifts in the business environment.jFrom the dynamic capabilities perspective, organizations need to adopt the supply chain dynamic capabilities, which enables the organization to meet changes and successfully sustain the organization's competitive positions and long-term profitability (Narasimhan, et al., 2004; Stevenson and Spring, 2007). Supply chain capabilities are the processes of integrating the internal and external competences, resources, and information to enhance supply chain practices.

Many researchers and scholars have investigated the relationship between supply chain and operational performance. Morash (2001), Kristal et al. (2010), Miguel and Brito (2011) argue that supply chain practices positively

Received: 2nd May 2020; revised: 5th October 2020; accepted: 12th October 2020 
enhance firm performance. Likewise, Gao \& Tian, (2014) state that the supply chain positively impacts enterprise performance. Hong et al. (2019) claim that supply chain quality management significantly affect both operational performance and innovation performance. Yu et al. (2018) explore the impact of data-driven supply chain capabilities on financial performance. These reviews show that the existing literature is primarily focused on the traditional supply chain practices and their impact on operational performance in a static business environment.

There has been rather limited research on supply chain dynamic capabilities, and how they can impact on firm performance in a dynamic business environment. Ju et al. (2016) argue that dynamic supply chain capabilities (information sharing, collaboration, integration, and agility) have a significant and positive relationship with technological innovation and operational performance of the organization. Namusonge (2017) argues that supply chain capabilities influence firm performance. Mandal et al. (2016) state that supply chain capabilities of collaboration, flexibility, velocity, and visibility positively influence supply chain resilience and supply chain performance. Some researchers have attempted to explore the indirect relationship between supply chain capabilities and operational performance. (Fung \& Chen, 2010) state that human capital moderates the relationship between supply chain capabilities and firm performance. Oh et al. (2019) argue that supply chain capabilities influence a firm's performance through the mediating role of information technology.

Despite these efforts, the direct impact of supply chain dynamic capabilities has been largely ignored. To fill this gap in our understanding, this paper aims to investigate the impact of supply chain dynamic capabilities on operational performance and attempts to empirically address the research question:

How do dynamic supply chain capabilities influence operational performance?

The objective of this paper is to answer this research question by proposing an empirical model that demonstrates that dynamic supply chain capabilities (collaboration capability, integration capability, agility capability, and responsiveness capability) have a positive impact on operational performance in the manufacturing industry in Hungary.

The study contributes to the literature by giving a better understanding of the nature of the relationship between supply chain dynamic capabilities and operational performance. Also, this study provides an empirical model that demonstrates the hypothesized relationship between supply chain dynamic capabilities and operational performance.

The next parts of this paper are organized in the following manner. Section two presents the literature review while section three discusses the methodology. The empirical results and findings are discussed in section four while section five provides the dissection and conclusion along with the theoretical and practical implications of the study.

\section{Literature review and hypotheses development}

\subsection{Dynamic supply chain capabilities}

This study is based on the dynamic capabilities theory. The concept of dynamic capabilities has emerged due to uncertainty and continual changes in the business environment and market. The dynamic capabilities theory pwas developed by Teece et al. (1997). They define dynamic capabilities as a firm's ability to build, integrate and reconfigure its internal and external resources and competences to cope with the rapid changes in the business environment." Zahra \& George, (2002) argue that dynamic capabilities enable" firms to renew and reconfigure their resource base to meet evolving lcustomer demands and competitor strategies.

The use of dynamic capabilities in the supply chain is becoming increasingly important (Witcher et al., 2008 \& Allred et al., 2011). The emergence of dynamic capabilities in the supply chain are due to the changes in the long and short-term supply and demand, market structure and customer requirements (Ju et al., 2016). Therefore, firms must have dynamic supply chain capabilities to address these changes. Through dynamic supply chain capabilities, firms can create a collaborative relationship with lother organizations, customers and suppliers and precisely predict market demands, in turn, enhancing the supply chain responsiveness to meet customer and supplier needs (Sanders, 2014).

Several researchers have investigated the dynamic capabilities from a supply chain perspective. Mathivathanan et al. (2017) argue that the development of dynamic capabilities through the supply chain has an important role to deal with future needs. Oh et al. (2019) describe dynamic supply chain capabilities as a firm's ability to sense and exploit internal and external resources in order to enhance supply chain practices efficiently and effectively. They also state that dynamic supply chain capabilities include sharing information, coordination, integration, and supply chain responsiveness. Ju et al. (2016) argue that dynamic supply chain capabilities are processes of information exchange, supply chain alignment, and information technology in order to meet customer needs and maintain competitiveness in a dynamic environment." Aslam et al. (2018) suggest that supply chain agility and adaptability are coherent components of dynamic supply chain capabilities which should be integrated to support supply chain ambidexterity. Many studies (Teece, 2007; Ju et al, 2016 and Yu et al, 2018) argue that dynamic capabilities are the 
high-order capabilities and this can be disaggregated into different capacities. Thus, in our study, the supply chain dynamic capabilities were disaggregated into the collaboration capability, integration capability, agility capability, and responsiveness capability. Each of the four dimensions reflects a firm's ability to meet customer needs and market requirements in order to achieve sustainable competitive advantage in a dynamic environment.

Collaboration capability refers to a firm's ability to build a long-term partnership in terms of supply chain activities and exchange of information, resources, and risk to achieve common objectives (Bowersox et al., 2002). Cao and Zhang (2011) argue that supply chain collaboration capability is an organization's capability to share information, knowledge and resource, goal consistency. Yunus (2018) discusses that customer collaboration, supplier collaboration, and internal collaboration are important elements to constitute the collaboration supply chain.

Integration capability indicates the firm's capacity to build strategic relationships and collaborate with its supply chain partners (Flynn et al., 2010). Supply chain integration emphasizes the availability of the right products, to the right consumers, at the right time at a competitive price (Angeles, 2009). Rajaguru and Matanda (2019) argue that supply chain integration consists of information flow integration, physical flow integration, and financial flow integration.

Agility capability refers to the firm's ability to respond speedily to the changes and turbulence in the market in order to enhance its suppliers and customers (Aslam et al., 2018). Moreover, supply chain agility is a dynamically process to adjust or reconfigure the current business process to address the shits in the market and other uncertainty. Li et al., (2009) suggest that supply chain agility consists of important elements are strategic readiness and response capability, operational readiness and response capability, and episodic readiness and response capability.

Responsiveness capability is defined as the ability of supply chain partners to respond to changes and shifts in the environment (Williams et al., 2013). Singh and Sharma (2015) allude that supply chain responsiveness emphasizes a reduction in lead time, improves service quality, quick response to a customer's requirements, and transportation optimization. Shekarian et al., (2020) argue that responsiveness in supply chain has three key elements: first, agility to respond to customer ineeds; second, flexibility to ensues a new product development and entering new markets and third, reduce the risk of supply chain bottlenecks and disruptions.

\subsection{Operational performance}

In a dynamic environment, firms strive to obtain competitive advantages and achieve excellent organizational performance (Rajaguru and Matanda, 2019). Operational performance is related to the firm's internal operations efficiency, which may enable the firm to enhance its competitiveness and profitability in the market (Hong et al., 2019). Operational performance is a multidimensional construct that includes the effective transformation of operational capabilities into competitive advantages of organizations. It can be assessed by productivity, quality, cost, delivery, flexibility, and customer satisfaction (Gambi et al., 2015; Ju et al., 2016; Saleh, et al., 2018). We now try to investigate and understand how dynamic supply chain capabilities interrelate and impact on operational performance as shown follows.

\subsection{Supply chain collaboration capability's contribution to operational performance}

Previous studies suggested that supply chain collaboration benefits include acquisition, sharing and development of new knowledge, learning capability, risk-sharing, and collaborative communication (Cao et al., 2010). Simatupang and Sridharan (2005) propose a supply chain collaboration index to measure the level of collaborative practices and find that the collaboration index positively impacts on operational performance. Cao and Zhang, (2011) argue that supply chain collaboration enhances collaborative advantage that enables supply chain partners to improve synergies and achieve superior performance. Jimenez et al. (2018) state that the supply chain collaboration with external partners boosts both incremental and radical innovations. Stank et al. (2001) suggest that both internal and external partnerships are important to ensure performance. Collaboration can increase profitability, reduce purchasing costs, and enhance technical cooperation. Thus, this study hypothesizes:

H1: Collaboration capability has a significant positive impact on operational performance.

\subsection{Supply chain integration capability's contribution to operational performance}

Supply chain integration capability is a set of continuous restructuring activities to facilitate a firm to reorganizing processes and resources more effectively, thus enhancing operational performance (Chen et al., 2009; Wu et al., 2006) argue that supply chain integration capabilities that are established with the organizational processes are likely to have a good potential to achieve a set of organizational performance. Oh et al. (2016) state that supply chain integration contributes to improving firm performance through reducing the bullwhip effect in the supply chain and sup- 
port a firm to respond to demands of the market more quickly. Flynn et al. (2010) insatiate the impact of supply chain integration on operational performance. They found that supply chain integration was significantly related to both operational and business performance. Furthermore, the results indicated that internal and customer integration were more strongly related to improving performance than supplier integration. Accordingly, we hypothesize that:

$\mathrm{H} 2$ : Integration capability has a significant positive impact on operational performance.

\subsection{Supply chain agility capability contributes to operational performance}

In today's dynamic and uncertain business environment, firms need to pay efforts to their supply chain risk to boost the agility and resilience of their supply chain systems (Tang and Tomlin, 2008).

Supply chain agility capability enables a firm to effectively match the internal and external resources to market changes. This capability helps a firm's efforts to take advantage of opportunities or counteract threats from turbulent environments (Van Hoek et al., 2001), which may lead to the achievement or maintenance of a competitive position (Eisenhardt and Martin 2000). Many studies state that the continuous improvement in supply chain agility capability, that is, improving the responsiveness to changes at small costs, has a positive impact on firm performance and competitiveness (Blome et al., 2013; Chakravarty et al., 2013; Oh et al., 2018). Moreover, (Vinodh et al., 2011) argue that supply chain agility may be able to enhance the operational performance by a more effective response to external supply disruptions, provides significant benefits for the internal processes of the firm, lower cost, improves quality, and delivery performance. Accordingly, we hypothesize that:

H3: Agility capability has a significant positive impact on operational performance.

\subsection{Supply chain responsiveness contributes to operational performance}

In today's rapidly changing business environment, supply chain responsiveness has become a highly significant capability of a firm's supply chain system (Williams et al., 2013). Supply chain responsiveness is a firm's ability to responds quickly to changes in consumer needs, production and delivery quantities and, product mix, volume, and delivery in response to shifts in demand and supply. These changes are most likely to lead to enhancing performance outcomes such as a lower production cost, greater customer satisfaction, and faster delivery (Yu et al., 2016). Moreover, (Prajogo and Olhager, 2016; Mandal et al., 2016) show that supply chain responsiveness positively impacts on operational performance. Accordingly, we hypothesize that:

H4: Supply chain responsiveness capability has a significant positive impact on operational performance.

This study develops an empirical research model considering the above-mentioned hypothesizes and theoretical background as it is shown in Fig.1.

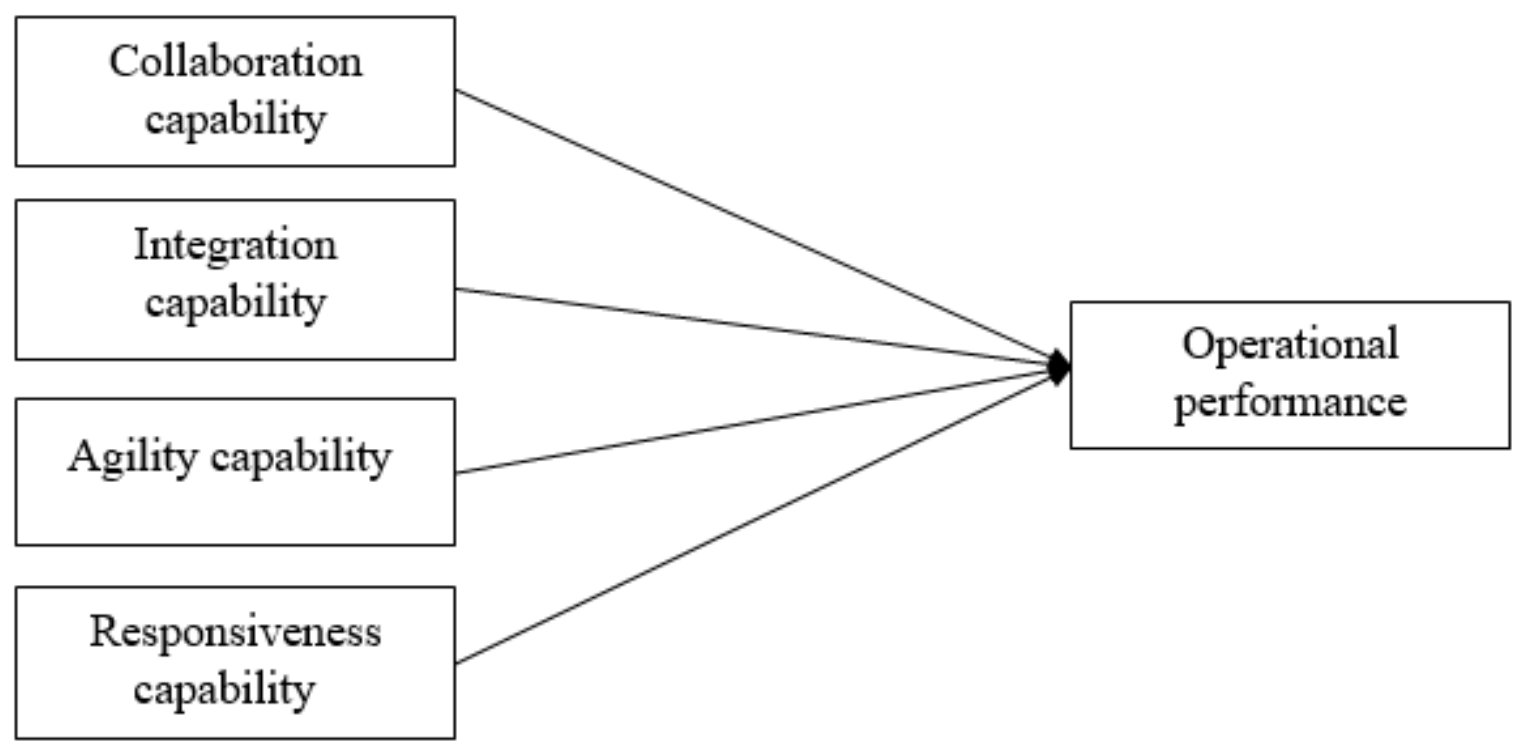

Figure 1: Conceptual model 


\section{Research Methodology}

\subsection{Questionnaire design and measures}

In order to assess the proposed hypotheses, we conducted a survey to managers, supervisors, and management personnel of manufacturing enterprises in Hungary. The survey instrument was developed based on the literature. The survey questionnaire was created by the google-forms tool. It was divided into three sections, namely: respondent and organization profile, dynamic supply chain capabilities, and operational performance.

The measurements were developed based on an extensive review of the literature. All measurements used a seven-point Likert scale. Dynamic supply chain capabilities were operationalized in four-dimensional constructs including collaboration capability, integration capability, agility capability, and responsiveness capability. Twenty items used for measuring dynamic supply chain capabilities were adopted from Ju et al. (2016), Wu et al. (2006), Aslam»et al. (2018), Oh et al. (2019), Hong'et al. (2019), and Rajaguru \& Matanda, (2019). Seven items measuring operational performance were adopted from Flynn' et al. (2010), Yu et al. (2018), and Rajaguru \& Matanda, (2019). The list of measurement items is presented in Appendix 1.

\subsection{Control variables}

The firm size and firm age were used as control variables in our model. However, the firm type cannot be a control variable for our study because we validate the research model using data collected from manufacturing firms (Hong et al., 2017). The firm age is a potential characteristic that has a considerable impact on firm performance. The number of employees was used as a proxy for the firm size because larger firms may have more resources for managing supply chain activities, and thus may achieve higher business performance than small firms (Yu et al., 2013).

\subsection{Data collection and sample description}

This study collected data from manufacturing companies in Hungary in the period 05/Jan.2020- 04/Mar.2020 by using an online questionnaire. To avoid the biases associated with convenience sampling (Hong et al., 2017). Thus, the manufacturing companies were selected randomly from the complete list of manufacturers in Hungary. The types of selected enterprises include private enterprises, state-owned enterprises, foreign-funded enterprises, and joint ventures. The investigated enterprises are involved in a wide range of activities such as furniture production, electricity production, clothing, pharmacy, food, electronic products, rubber, and plastic. The respondents mainly included several CEOs, presidents, directors, managers, supervisors, and senior staff who work in jobs related to supply chain management or operation management. We mailed the questionnaire, including a cover letter highlighting the study's objectives and the importance of the respondent's cooperation. Out of 235 companies contacted, a total of 421 questionnaires were distributed, out of which 208 completed questionnaires were obtained, with a response rate of $49.40 \%$ of the respondents. We distributed more than one questionnaire from the same firm. Because of several managers representing different organizational levels at the same time for one firm. Thus, supply chain dynamic capabilities should be involved the opinions not only from the CEO or president but also from operations and supply chain managers. This approach has the benefit of providing an overall perspective from the top executives and an expert perspective from the relevant functional area of the firm (Li et al., 2008; Yu, 2017).

The respondent profile information is presented in Table 1 . It shows that the majority of the companies (23.6\%) are food industry. Most of the companies at (33.2\%) are private companies. A little lower than half of the investigated companies were in the relatively large company classification of over 500 employees. Most of the companies $(36.5 \%)$ were more than 20 years old.

Table 1: Respondent profile information

\begin{tabular}{|l|l|c|c|}
\hline Characteristics & Categories & Frequency & Percentage]\%目 \\
\hline \multirow{4}{*}{ Industry } & Furniture production & 18 & 8.7 \\
\cline { 2 - 4 } & Electricity production & 21 & 10.1 \\
\cline { 2 - 4 } & Clothing & 15 & 7.2 \\
\cline { 2 - 4 } & Pharmacy & 19 & 9.1 \\
\cline { 2 - 4 } & Food & 49 & 23.6 \\
\cline { 2 - 4 } & Electronic products & 45 & 21.6 \\
\cline { 2 - 4 } & Rubber and plastic & 41 & 19.7 \\
\hline
\end{tabular}


Table 1: Respondent profile information (continues)

\begin{tabular}{|l|l|l|l|}
\hline \multirow{5}{*}{ Type of firm } & State-owned company & 35 & 16.8 \\
\cline { 2 - 4 } & Private company & 69 & 33.2 \\
\cline { 2 - 4 } & Foreign-owned & 62 & 29.8 \\
\cline { 2 - 4 } & Joint venture & 42 & 20.2 \\
\hline \multirow{5}{*}{ Size (Employees) } & Less than 100 & 54 & 26.0 \\
\cline { 2 - 4 } & |100-300 & 37 & 17.8 \\
\cline { 2 - 4 } & $301-500$ & 28 & 13.5 \\
\cline { 2 - 4 } & 501-1000 & 25 & 12.0 \\
\cline { 2 - 4 } & More than 1000 & 64 & 30.8 \\
\hline & Less than 4 years & 13 & 6.3 \\
\cline { 2 - 4 } & 4-5 years & 33 & 15.9 \\
\cline { 2 - 4 } & 6-10 years & 29 & 13.9 \\
\cline { 2 - 4 } & 11-20 years & 57 & 27.4 \\
\cline { 2 - 4 } & More than 20 years & 76 & 36.5 \\
\hline
\end{tabular}

\section{Data analysis and results}

\subsection{Descriptive statistics}

Table 2 presents descriptive statistics such (mean, standard deviation, and correlation). The results show that the means score for all the constructs is located between (3.28-4.91) and standard deviation (0.83-1.04) which indicates that the firms have a good implementation of supply chain dynamic capabilities. Also, the results show that each of the constructs is positively and significantly correlated with each other.

\subsection{Reliability and Validity}

The reliability and validity of measurement scales were assessed by using confirmatory factor analysis (CFA), and AMOS 24 was used to estimate convergent validity and discriminant validity. The reliability of the scales was evaluated using Cronbach's alpha coefficient as seen in (Table 3). Cronbach's alpha coefficient for all constructs ranges between 0.774 and 0.789 which are above the threshold value .50. This indicates that all the items are internally consistent (Hair et al., 2010). The convergent validity was determined in three important indicators, which are factor loadings (standardized estimates), Average Variance Extracted (AVE), and Composite Reliability (CR).

This study establishes that out of a total of 27 initial items, 24 items have been maintained (see in Table 3). This indicates that the 3 items were deleted because of poor loadings. The remaining 24 items retained should be loaded highly on one factor with a factor loading of 0.50 or greater and statistically significant $(\mathrm{p}<0.05)$ as recommended by Hair et al. (2010). Composite reliability (CR) for all constructs ranges between 0.830 and 0.898 which are above 0.50 , indicating that all the constructs demonstrate a good level of composite reliability (CR) as recommended by Hair et al. (2012). The average variance extracted (AVE) value for all the constructs is located between 0.707 to 0.764 which is above the threshold value (.50) which is suggested by Hair et al., (2010).

Discriminant validity was examined by using (Fornell \& Larcker, 1981) method. They suggested that if the

Table 2: Descriptive statistics

\begin{tabular}{|l|l|l|l|l|l|l|l|}
\hline & Mean & S.D. & CC & IC & AC & RC & OP \\
\hline CC & 3.53 & 0.92 & 1 & & & & \\
\hline IC & 3.37 & 0.87 & $0.624^{* *}$ & 1 & & & \\
\hline AC & 3.49 & 0.83 & $0.603^{* *}$ & $0.9510^{* *}$ & 1 & & \\
\hline RC & 3.28 & 0.91 & $0.547^{* *}$ & $0.638^{* *}$ & $0.680^{* *}$ & 1 & \\
\hline OP & 4.91 & 1.04 & $0.480^{* *}$ & $0.551^{* *}$ & $0.689^{* *}$ & $0.627^{* *}$ & 1 \\
\hline
\end{tabular}

**. Correlation is significant at the 0.01 level (2-tailed).

$\mathrm{CC}=$ Collaboration capability, $\mathrm{IC}=$ Integration capability, $\mathrm{AC}=$ Agility capability, $\mathrm{RC}=$ Responsiveness capability, $\mathrm{OF}=\mathrm{Operational}$ performance. Measurement Items used for the constitution of the listed variables are presented in Appendix 1. 
Table 3: CFA results: reliability and validity.

\begin{tabular}{|c|c|c|c|c|c|c|}
\hline Constructs & $\begin{array}{c}\text { Measurement } \\
\text { Items }\end{array}$ & $\begin{array}{l}\text { Factor } \\
\text { Loading }\end{array}$ & a & $\mathrm{CR}$ & AVE & P.Value \\
\hline \multirow{5}{*}{$\begin{array}{l}\text { Collaboration capa- } \\
\text { bility }\end{array}$} & $\mathrm{CC} 1$ & 0.717 & \multirow[t]{5}{*}{0.778} & \multirow[t]{5}{*}{0.878} & \multirow[t]{5}{*}{0.716} & 0.000 \\
\hline & $\mathrm{CC} 2$ & 0.774 & & & & 0.000 \\
\hline & $\mathrm{CC} 3$ & 0.787 & & & & 0.000 \\
\hline & $\mathrm{CC} 4$ & 0.723 & & & & 0.000 \\
\hline & CC5 & deleted & & & & \\
\hline \multirow{5}{*}{$\begin{array}{l}\text { Integration } \\
\text { capability }\end{array}$} & IC1 & 0.624 & \multirow[t]{5}{*}{0.783} & \multirow[t]{5}{*}{0.830} & \multirow[t]{5}{*}{0.751} & 0.000 \\
\hline & IC2 & deleted & & & & \\
\hline & IC3 & 0.614 & & & & 0.000 \\
\hline & IC4 & 0.591 & & & & 0.000 \\
\hline & IC5 & 0.635 & & & & 0.000 \\
\hline \multirow{5}{*}{$\begin{array}{c}\text { Agility } \\
\text { capability }\end{array}$} & AC1 & 0.688 & \multirow[t]{5}{*}{0.785} & \multirow{10}{*}{0.874} & \multirow[t]{5}{*}{0.727} & 0.000 \\
\hline & $A C 2$ & 0.621 & & & & 0.000 \\
\hline & AC3 & 0.572 & & & & 0.000 \\
\hline & AC4 & 0.683 & & & & 0.000 \\
\hline & AC5 & 0.695 & & & & 0.000 \\
\hline \multirow{5}{*}{$\begin{array}{l}\text { Responsiveness } \\
\text { capability }\end{array}$} & $\mathrm{RC} 1$ & 0.559 & \multirow[t]{5}{*}{0.774} & & \multirow[t]{5}{*}{0.707} & 0.000 \\
\hline & $\mathrm{RC2}$ & 0.685 & & & & 0.000 \\
\hline & $\mathrm{RC} 3$ & 0.583 & & & & 0.000 \\
\hline & $\mathrm{RC} 4$ & 0.581 & & & & 0.000 \\
\hline & $\mathrm{RC5}$ & 0.663 & & & & 0.000 \\
\hline \multirow{7}{*}{$\begin{array}{l}\text { Operational } \\
\text { performance }\end{array}$} & OP1 & 0.599 & \multirow[t]{7}{*}{0.789} & \multirow[t]{7}{*}{0.898} & \multirow[t]{7}{*}{0.764} & 0.000 \\
\hline & OP2 & 0.669 & & & & 0.000 \\
\hline & OP3 & deleted & & & & 0.000 \\
\hline & OP4 & 0.614 & & & & 0.000 \\
\hline & OP5 & 0.611 & & & & 0.000 \\
\hline & OP6 & 0.601 & & & & 0.000 \\
\hline & OP7 & 0.687 & & & & 0.000 \\
\hline
\end{tabular}

$\mathrm{a}=$ Cronbach's alpha, $\mathrm{CR}=$ Composite Reliability and Average, $\mathrm{AVE}=$ Variance Extracted

square root of the AVE for a latent construct is greater than the correlation values among all the latent variables that means discriminant validity is supported. Table 4 shows that the square root of the AVE values of all the constructs is greater than the inter-construct correlations which confirm discriminant validity. Also, Hair et al. (2010) suggest that if AVE for a latent construct is larger than the maximum shared variance (MSV) with other latent constructs that provides evidence of discriminant validity. The goodnessof-fit measures were used to assess the fitness of a measurement model. The results confirm an adequate model fit $(\mathrm{CMIN} / \mathrm{df}=1.431, \mathrm{GFI}=0.873, \mathrm{TLI}=0.898, \mathrm{CFI}=0.899$,
RMSEA $=0.047)$. Thus, the measurement model indicates good construct validity and reliability. 
Table 4: Discriminant validity

\begin{tabular}{|c|c|c|c|c|c|c|c|}
\hline & AVE & MSV & CC & IC & AC & RC & OP \\
\hline CC & 0.716 & 0.568 & $\mathbf{0 . 8 4 6}$ & & & & \\
\hline IC & 0.751 & 0.466 & 0.332 & $\mathbf{0 . 8 6 7}$ & & & \\
\hline AC & 0.727 & 0.604 & 0.432 & 0.478 & $\mathbf{0 . 8 5 3}$ & & \\
\hline RC & 0.707 & 0.504 & 0.664 & 0.603 & 0.332 & $\mathbf{0 . 8 4 1}$ & \\
\hline OP & 0.764 & 0.361 & 0.621 & 0.731 & 0.635 & 0.719 & $\mathbf{0 . 8 7 4}$ \\
\hline
\end{tabular}

Notes: Bold values in diagonal represent the squared root estimate of AVE. $\mathrm{AVE}=$ Average Variance Extracted, MSV= Maximum shared variance.

\subsection{Common method bias checks}

The Harman one-factor test (Podsakoff \& Organ, 1986) was used to test for common method bias. A principal component analysis (PCA) was performed for all the items included in the study. The results show that the total variance for a single factor is less than $50 \%$. We conclude that common method bias does not confound the interpretations of the results.

\subsection{Test of hypotheses}

The structural equation modeling (SEM) was used to test empirically the proposed hypotheses. The results of the hypothesis test are shown in Table 5 and Fig. 3. The results show that collaboration capability $(B=0.446$, $\mathrm{p}<0.001)$, agility capability $(\mathrm{B}=0.552, \mathrm{p}<0.001)$, and responsiveness capability $(\mathrm{B}=0.266, \mathrm{p}<.0 .021)$ significantly and positively impact on an operational performance, which strongly supports H1, H3, and H4. However, there was no significant relationship between integration capability $(\mathrm{B}=0.096, \mathrm{p}<0.373)$ and operational performance. Hence, $\mathrm{H} 2$ is rejected.

Table 5: Result of hypothesis Test

\begin{tabular}{|c|c|c|c|c|}
\hline No. & Hypotheses & $\begin{array}{l}\text { Beta Coeffi- } \\
\text { cient }\end{array}$ & P.Value & Result \\
\hline $\mathrm{H} 1$ & Collaboration capability $\rightarrow$ Operational Performance & 0.446 & 0.00 & Supported \\
\hline $\mathrm{H} 2$ & Integration Capability $\rightarrow$ Operational Performance & 0.096 & .373 & Not Supported \\
\hline H3 & Agility Capability $\rightarrow$ Operational Performance & 0.552 & 0.00 & Supported \\
\hline H3 & Responsiveness Capability $\rightarrow$ Operational Performance & 0.266 & .021 & Supported \\
\hline
\end{tabular}




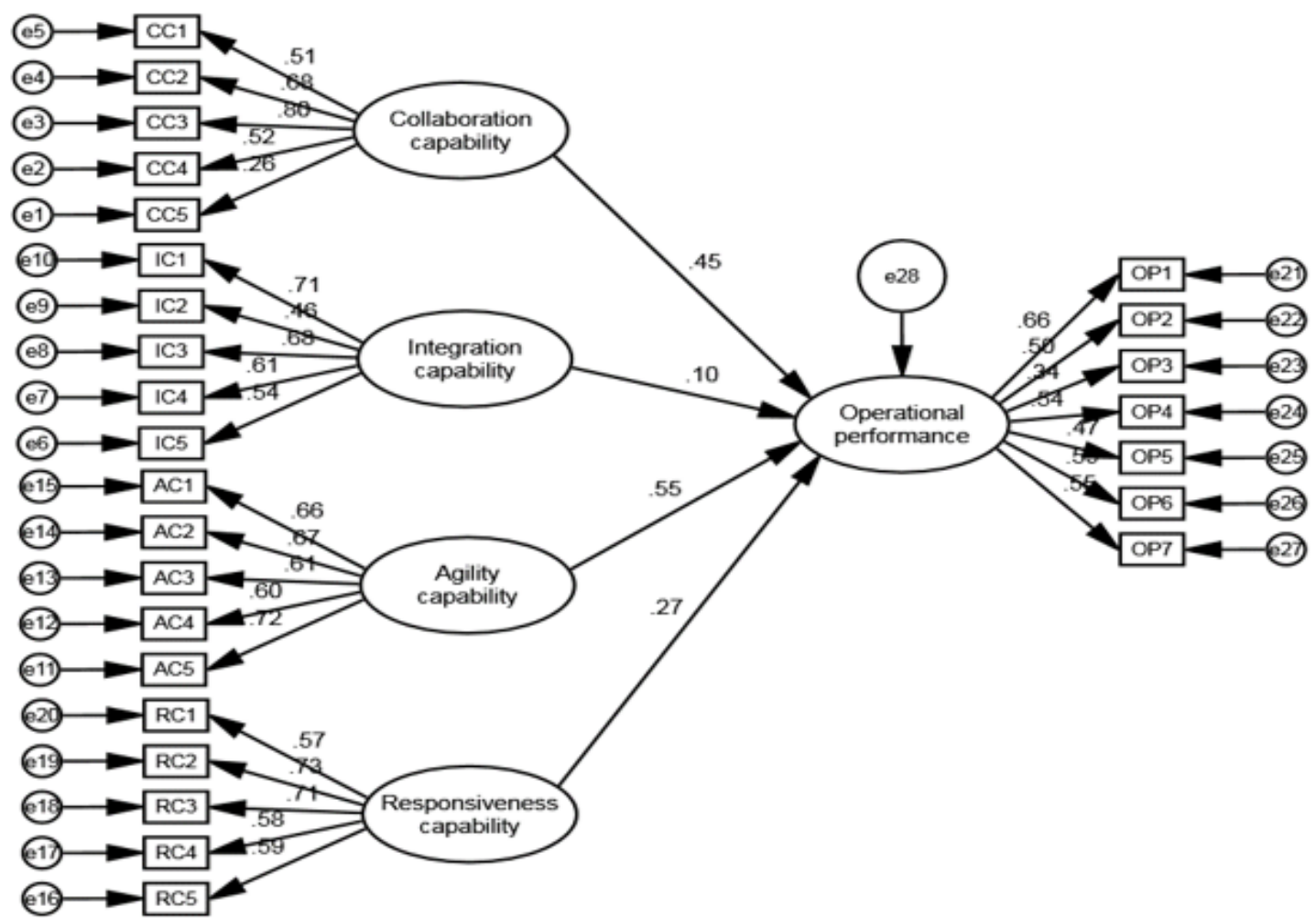

Figure 2: The SEM model analysis

\section{Discussion and conclusion}

This study investigates the interaction impact between supply chain dynamic capabilities and operational performance. In particular, we evaluate the impact of four supply chain dynamic capabilities, namely collaboration capability, integration capability, agility capability, and responsiveness capability on the operational performance of manufacturers in Hungary. The study revealed four key findings. First, we find that collaboration capability has a significant positive impact on operational performance. This is in line with the results of Yu et al. (2018). They argue that when a firm builds a good relationship with partners, collaboration supply chain capability has a potential impact on firm operational performance. Our finding is also consistent with the results of Cao and Zhang, (2011) which indicate that supply chain collaboration capability improves collaborative advantage, in turn, positively impacts firm performance. Second, this study finds that integration supply chain capability has no significant impact on operational performance. This finding is significantly different from some previous studies. For example, Flynn et al. (2010) argue that integration supply chain capability positively influences operational performance through customer and supplier integration. However, a potential reason for the inconsistent findings may be due to the fact that it is not an easy task for firms and their partners to implement effective integration supply chain to ensure their objectives (Shashi et al., 2019). Third, we find that agility supply chain capability has the highest significant positive relationship with operational performance. This is in line with the results of (Aslam et al., 2018). They state that supply chain agility capability enables a firm to grab opportunities in the marketplace that may enhance the firm's performance. Our findings are also consistent with the results of Oh et al. (2018). They argue that the agility supply chain contributes to a firm's operational performance through the quick speed to market and customer satisfaction. Fourth, this study finds that supply chain responsiveness capability positively influences operational performance. This is in line with the results of Aslam et al. (2018) and Hong et al. (2019). They argue that a firm's ability to respond quickly to changing consumer needs, to competitors' strategies, and to develop new products quickly can improve its performance. Finally, this study concludes that in a changing environment, supply chain dynamic capabilities such as collaboration capability, agility capability, and responsiveness capability have a positive impact on operational performance. 


\subsection{Theoretical contributions}

This study provides two important theoretical contributions. First, although researches on the supply chain have attracted considerable attention in literature, very limited researches have been done on supply chain dynamic capabilities. Therefore, this study introduces an empirical approach to investigating the impact of supply chain dynamic capabilities on operational performance. Thus, it has important potential to fills the gap in the literature. Second, the study contributes to supply chain literature by demonstrating a clear understanding of the specific supply chain dynamic capabilities that firms need to develop in order to enhance operational performance. Moreover, we find that these supply chain dynamic capabilities are multidimensional, measurable, and applicable which will help scholars to use these measurements in future research.

\subsection{Managerial implications}

This study provides important practical implications for manufacturers. To survive in changing environments, managers should recognize the role of supply chain dynamic capabilities in improving operational performance. Our results confirm that collaboration capability, agility capability, and responsiveness capability are significantly and positively associated with operational performance. Also, the results show that integration capability has no positive association with operational performance. The study suggests that building these capabilities can help manufacturing managers to build effective supply chains and achieve superior performance. Further, managers need to recognize that supply chain dynamic capabilities are multidimensional and each dimension has differential effects on operational performance. Thus, manufacturing firm managers have to focus on the supply chain dynamic capabilities that need to be targeted to improve operational performance.

\subsection{Limitations and future research}

This study has some limitations that need to be addressed in future research. First, the study applied cross-sectional research design, thus findings of this study cannot be considered as definitive evidence of the underlying causal relationships. Future research may use a longitudinal research design that could give conclusive evidence for the highlighted relationships. Second, this study used self-reported data for measuring the variables of the study. Future research may employ dataset with knowledgeable informants from each firm that may enhance the validity of the findings. Third, this study focuses on four dimensions of supply chain dynamic capabilities. Future research should consider other potential dimensions.

\section{Literature}

Allred, C., Fawcett, S., Wallin, C., \& Magnan, G. (2011). A dynamic collaboration capability as a source of competitive advantage. Decision Sciences, 42(1), 129-161. https://doi.org/10.1111/j.1540-5915.2010.00304.x

Angeles, R. (2009). Anticipated IT infrastructure and supply chain integration capabilities for RFID and their associated deployment outcomes. International Journal of Information Management, 29(3), 219-231. https:// doi.org/10.1016/j.ijinfomgt.2008.09.001

Aslam, H., Blome, C., Roscoe, S., Tashfeen M., \& Azhar, T.M. (2018). Dynamic supply chain capabilities: How market sensing, supply chain agility and adaptability affect supply chain ambidexterity. International Journal of Operations \& Production Management, 38(12), 2266-2285. https://doi.org/10.1108/ IJOPM-09-2017-0555

Blome, C., Schoenherr, T., \& Rexhausen, D. (2013). Antecedents and enablers of supply chain agility and its effect on performance: a dynamic capabilities perspective. International Journal of Production Research, 51(4), 1295-1318. http://doi.org/10.1080/00207543.2 012.728011

Bowersox, D. J., Closs, D. J., \& Cooper, M. B. (2002). Supply Chain Logistics. McGraw Hill.

Cao, M., \& Zhang, Q. (2011). Supply chain collaboration: impact on collaborative advantage and firm performance. Journal of Operations Management, 29(3), 163-180. https://doi.org/10.1016/j.jom.2010.12.008

Cao, M., Vonderembse, M.A., Zhang, Q. and \& Ragu-Nathan, T.S. (2010). Supply chain collaboration: conceptualization and instrument development, International Journal of Production Research, 48(22), 6613-6635. https://doi.org/10.1080/00207540903349039

Chakravarty A., Grewal R., \& Sambamurthy V. (2013). Information technology competencies, organizational agility, and firm performance: enabling and facilitating roles. Information Systems Research, 24(4), 976-997. https://doi.org/10.1287/isre.2013.0500

Chen, H., Daugherty, P., and Roath, A. (2009). Defining and operationalizing supply chain process integration capabilities, Journal of Business Logistics, 30(1), 63-84. http://doi.org/10.1002/j.2158-1592.2009.tb00099.x

Eisenhardt, K.M., \& Martin, J.A. (2000). Dynamic capabilities: what are they? Strategic Management Journal, 21, 1105-1121. https://doi.org/10.1002/10970266(200010/11)21:10/11<1105::AID-SM$\mathrm{J} 133>3.0 . \mathrm{CO} ; 2-\mathrm{E}$

Flynn, B., Huo, B., \& Zhao, X. (2010). The impact of supply chain integration on performance: a contingency and configuration approach. Journal of Operations Management, 28(1), 58-71. https://doi.org/10.1016/j. jom.2009.06.001

Fornell, C., \& Larcker, D. (1981). Structural equa- 
tion models with unobservable variables and measurement error: Algebra and statistics. Journal of Marketing Research, 18(34), 382-388. https://doi. org/10.1177/002224378101800313

Fung, P. K., \& Chen, S. (2010). Human capital for supply chain management capabilities: a study of international trade intermediaries. International Journal of Logistics Research and Applications: A Leading Journal of Supply Chain Management, 13(1), 1-12. https://doi. org/10.1080/13675560902746403

Gambi, L. D., Boer, H., Gerolamo, M. C., Jørgensen, F., \& Carpinetti, L. C. (2015). The relationship between organizational culture and quality techniques, and its impact on operational performance. International Journal of Operations \& Production Management, 35(10), 1460-1484. https://doi.org/10.1108/ IJOPM-12-2013-05633

Gao, T., \& Tian, Y. (2014). Mechanism of Supply Chain Coordination based on Dynamic Capability Framework-the mediating Role of Manufacturing Capabilities. Journal of Industrial Engineering and Management, 7(5), 1250-1267. http://dx.doi.org/10.3926/ jiem. 1266

Hair, J., Sarstedt, M., Ringle, C., \& Mena, J. (2012). An assessment of the use of partial least squares structural equation modeling in marketing research. Journal of the Academy of Marketing Science, 40(3), 414-433. https://doi.org/10.1007/s11747-011-0261-6

Hair, J.F., Black, W. C., Babin, B.J., \& Anderson, R. \&. (2006). Multivariate Data Analysis. Upper Saddle River, NJ: Pearson Prentice Hall.

Hair, J.F., Black,, W. C., Babin., \& B.J., and \& Anderson, R. (2010). Multivariate data Analysis: a global perspective. Delhi: Pearson Education.

Hong, J., Liao, Y., Zhang, Y., \& Yu, Z. (2019). The effect of supply chain quality management practices and capabilities on operational and innovation performance: Evidence from Chinese manufacturers. International Journal of Production Economics, 212, 227-235. https://doi.org/10.1016/j.ijpe.2019.01.036

Jimenez-Jimenez, D., Martínez-Costa, M. and \& Sanchez Rodriguez, C. (2019). The mediating role of supply chain collaboration on the relationship between information technology and innovation. Journal of Knowledge Management, 23(3), 548--567. https://doi. org/10.1108/JKM-01-2018-0019

Ju, K.-J., Park, B., \& Kim, T. (2016). Causal Relationship between Supply Chain Dynamic Capabilities, Technological Innovation, and Operational Performance. Management and Production Engineering Review, 7(4), 6-15. http://doi.org/10.1515/mper-2016-0031

Kristal M.M., Huang X., \& Roth A.V.(2010). The effect of an ambidextrous supply chain strategy on combinative competitive capabilities and business performance, Journal of Operations Management, 28(5), 145-429. https://doi.org/10.1016/j.jom.2009.12.002
Li, X., Goldsby, T. J., \& Holsapple, C. W. (2009). Supply chain agility: scale development. The International Journal of Logistics Management, 20(3), 408-424. https://doi.org/10.1108/09574090911002841

Mandal, S., Sarathy, R., Korasiga, V.R., Bhattacharya, S. and \& Dastidar, S.G. (2016). Achieving supply chain resilience: The contribution of logistics and supply chain capabilities. International Journal of Disaster Resilience in the Built Environment, 7(5), 544562. https://doi.org/10.1108/IJDRBE-04-2016-0010

Mathivathanan, D., Govindan, K., \& Haq, A. N. (2017). Exploring the impact of dynamic capabilities on sustainable supply chain firm's performance using Grey-Analytical Hierarchy Process. Journal of Cleaner Production, 147, 637-653. https://doi.org/10.1016/j. jclepro.2017.01.018

Miguel P.L.S., \& Ledur Brito L.A.L. (2011). Supply chain management and its influence on operational performance. Journal of Operations and Supply Chain Management, 4(2), 56-70. http://doi.org/10.12660/joscm$\mathrm{v} 4 \mathrm{n} 2 \mathrm{p} 56-70$

Morash, E. A. (2001). Supply Chain Strategies, Capabilities, and Performance. Transportation Journal, 41(1), 37-54. https://www.jstor.org/stable/20713481

Namusonge, E. (2017). Influence of Supply Chain Capabilities on Firm Performance of Manufacturing Entities in Kenya. University of Agriculture and Technology.

Narasimhan R., Talluri S., \& Das A. (2004). Exploring flexibility and execution competencies of manufacturing firms, Journal of Operations Management, 22(1), 91-106. https://doi.org/10.1016/j.jom.2003.12.003

Oh, S., Ryu, Y. U., \& Yang, H. (2019). Interaction effects between supply chain capabilities and information technology on firm performance. Information Technology and Management, 20, 91-106. https://doi. org/10.1007/s10799-018-0294-3

Podsakoff, P. M., \& Organ, D. W. (1986). Self-reports in organizational research: Problems and prospects. Journal of Management, 12(1), 531-544.

Prajogo, D., Oke, A., and \& Olhager, J. (2016). Supply chain processes: linking supply logistics integration, supply performance, lean processes and competitive performance, International Journal of Operations \& Production Management, 36(2), 220-238. https://doi. org/10.1108/IJOPM-03-2014-0129

Rajaguru, R., \& Matanda, M. J. (2019). Role of compatibility and supply chain process integration in facilitating supply chain capabilities and organizational performance. Supply Chain Management: An International Journal, 24(2), 301-316. https://doi.org/10.1108/ SCM-05-2017-0187

Saleh, R., Sweis, J., \& Saleh, F. (2018). Investigation the impact of hard total quality management practices on operational performance in manufacturing organizations: evidence from Jordan. Benchmarking: An International Journal, 25(7), 2040-2064. https://doi. 
org/10.1108/BIJ-05-2016-0074

Sanders, N. (2014). Big Data Driven Supply Chain Management: A Framework for Implementing Analytics and Turning Information Into Intelligence. Pearson Financial Times.

Shashi, Tavana, M., \& Shabani, A. (2019). The impact of interwoven integration practices on supply chain value addition and firm performance. Journal of Industrial Engineering International, 15, 39-51. https://doi. org/10.1007/s40092-019-0316-8

Shekarian, M., Nooraie, S., \& Parast, M. (2020). An Examination of the Impact of Flexibility and Agility on Mitigating Supply Chain Disruptions. International Journal of Production Economics, 220, 1-46. https:// doi.org/10.1016/j.ijpe.2019.07.011

Simatupang, T.M., \& Sridharan, R., (2005). An Integrative framework for supply chain collaboration. International Journal of Logistics Management, 16(2), 257-274.ן

Singh, R. K., \& Sharma, M. K. (2015). Selecting a competitive supply chain using fuzzy-AHP and extent analysis. Journal of Industrial and Production Engineering, 31(8), 524-538. https://doi.org/10.1080/2168 1015.2014.999723

Stank, T.P., Keller, S.B., \& Daugherty, P.J. (2001). Supply chain collaboration and logistical service performance. Journal of Business Logistics, 22(1), 29-48. http://doi. org/ 10.1002/j.2158-1592.2001.tb00158.x

Stevenson M., \& Spring M., (2007). Flexibility from a supply chain perspective: definition and review, International Journal of Operations \& Production Management, 27(7), 685-713. https://doi. org/10.1108/01443570710756956

Tang, C., \& Tomlin, B. (2008). The power of flexibility for mitigating supply chain risks. International Journal of Production Economics, 116(1), 12-27. https://doi. org/10.1016/j.ijpe.2008.07.008

Teece, D.J, \& Pisano, G.;Shuen, A. (1997). Dynamic capabilities and strategic management. Strategic Management Journal, 18(7), 509-533. https://doi.org/10.1002/ (SICI) 1097-0266(199708)18:7<509::AID-SM$\mathrm{J} 882>3.0 . \mathrm{CO} ; 2-\mathrm{Z}$

Van Hoek, R.I., Harrison, A. and \& Christopher, M. (2001). Measuring agile capabilities in the supply chain, International Journal of Operations and Production Management, 21(1/2), 126-147. http://doi. org/10.1108/01443570110358495

Williams, B., Roh, J., Tokar, T., \& Swink, M. (2013). Leveraging supply chain visibility for responsiveness: the moderating role of internal integration. Journal of Operations Management, 31(8), 543-554. https://doi. org/10.1016/j.jom.2013.09.003

Witcher, B., Chau, V., \& Harding, P. (2008). Dynamic capabilities: top executive audits and hoshin kanri at Nissan South Africa. International Journal of Operations \& Production Management, 28(6), 540-561. https:// doi.org/10.1108/01443570810875359

Wu, F., Yeniyurt, S., Kim, D., \& Cavusgil, T. (2006). The impact of information technology on supply chain capabilities and firm performance: A resource-based view. Industrial Marketing Management, 35, 493504. https://doi.org/10.1016/j.indmarman.2005.05.003

Yu, W., Chavez, R., Jacobs, M. A., \& Feng, M. (2018). Data-driven supply chain capabilities and performance: A resource-based view. Transportation Research, Part E 114, 371-385. https://doi.org/10.1016/j. tre.2017.04.002

Yunus, E. N. (2018). Leveraging supply chain collaboration in pursuing radical innovation. International Journal of Innovation Science, 10(3), 350-370. https://doi. org/10.1108/IJIS-05-2017-0039

Zahra, S., \& George, G. (2002). The net-enabled business innovation cycle and the evolution of dynamic capabilities. Information Systems Research, 13(2), 147-155. https://doi.org/10.1287/isre.13.2.147.90

Mohanad Ali Kareem is a Ph.D. candidate at Kaposvár University, Faculty of Economic Science, Doctoral School of Management and Organizational Science, Hungary. His research focuses on human resources management, strategic management, and organizational behavior.

Harsha Vardhan Reddy Kummitha is a researcher associate at Budapest Business School, Department of Hospitality and Tourism. Budapest, Hungary. His research focuses on sustainable tourism, ecotourism, eco-entrepreneurship. 


\section{Appendix A. List of Measurement Items: Supply Chain Dynamic Capabilities}

\section{Collaboration Capability}

$\mathrm{CC} 1$ : Our company operates an agreement with partners

$\mathrm{CC} 2$ : Our company collaborates actively in group decision making with partners

CC3: Our company collaborates actively in group problem solving with partners

CC4: Our company has a good relationship with partners

CC5: Our company develops strategic plans in |collaboration with our partners.

\section{Integration capability}

IC1: Our company ensures the standardization of data with partners

IC2: Our company ensures integration of information system with partners

IC3: Our company removes repetition with partners

IC4: Our company ensures data consistency with partners

IC5: Our company always forecasts and plans activities collaboratively with our partner

Agility capability

AC1: Our company adapts services and/or products to new customer requirements quickly

AC2: Our company reacts to new market developments quickly

AC3: Our company reacts to significant increases and decreases in demand quickly

AC4: Our company adjusts product portfolio as per market requirement

AC5: Our company responds to competitors strategy change more quickly than our competitors

Responsiveness capability

$\mathrm{RC} 1$ : Our company responds quickly to changing consumer needs

RC2: Our company ensures feedback to suppliers more quickly and effectively

RC3: Our company responses to the quality strategy of competitors more quickly and effectively

RC4: Our company responds quickly to changing scope of supply

RC5: Our company responses to the risk of the supply chain more quickly and effectively

\section{Operational performance}

OP1: Our company's effectiveness in fulfilling requirements.

OP2: Our company's effectiveness in responding to changes in market demand.

OP3: Our company's effectiveness in on-time delivery.

OP4: Our company's effectiveness in delivering reliable quality products.

OP5: Reduction in lead time to fulfill customers' orders.

OP6: Reduction in overhead costs

OP7: Reduction in inventory costs 